Brazilian Journal

of Chemical

ISSN 0104-6632

Engineering

Printed in Brazil

www.abeq.org.br/bjche

Vol. 24, No. 04, pp. 499 - 507, October - December, 2007

\title{
EFFECTS OF Aspergillus niger INOCULUM CONCENTRATION UPON THE KINETICS OF STARCHY WASTEWATER PRETREATMENT IN A TANKS-IN-SERIES BIOREACTOR UNDER TRANSITORY CONDITIONS
}

\author{
L. Coulibaly ${ }^{1 *}$ and S. N. Agathos ${ }^{2}$ \\ ${ }^{1}$ Laboratoire d'Environnement et de Biologie Aquatique (LEBA), \\ UFR-Sciences et Gestion de 1'Environnement, Phone: 00225-07-49-71-53, \\ Université d'Abobo-Adjamé, 02 BP 801 Abidjan 02, Côte d'Ivoire, Africa \\ E-mail coulacina2003@yahoo.fr) \\ ${ }^{2}$ Unit of Bioengineering (GEBI), Catholic University of Louvain, \\ Place Croix du sud 2/19 1348 Louvain-la-Neuve, Belgique, \\ E-mail: spiros.agathos@uclouvain.be
}

(Received: August 18, 2006 ; Accepted: September 6, 2007)

\begin{abstract}
This paper discusses the effects of three Aspergillus niger inoculum concentrations (0.12, 2.3 and $3.6 \mathrm{~g} / \mathrm{l})$ upon the kinetics of starch pretreatment under aerobic and transitory conditions using a tanks-in-series reactor. A synthetic wastewater containing starch as model polysaccharide was fed into the reactor system to study this polymer transformation by Aspergillus niger. Starch and metabolites (oligosaccharides with a molecular weight lower than $1 \mathrm{kDa}$ ) in the individual reactors were quantified respectively by the starch iodine complex (SIC) and anthrone methods. Enzyme activities were characterised with API ZYM kits. Starch degradation and metabolite accumulation were both influenced by both fungal inoculum and reactor HRT. Starch degradation improved from 34 to $99 \%$ with a parallel in increase inoculum concentration from 0.12 to $3.6 \mathrm{~g} / \mathrm{l}$. An overall of $400 \mathrm{mg} / \mathrm{l}$ of metabolites accumulated in the reactor system. A. niger secreted both extracellular and cell-wall-bound enzymes among which amylases.

Keywords: Starch; Pretreatment; Bioreactor; Enzyme; Aspergillus niger.
\end{abstract}

\section{INTRODUCTION}

The organic matter contained in domestic wastewater is typically composed of $40-60 \%$ proteins, $25-50 \%$ carbohydrates and $10 \%$ lipids. In addition 50 to $60 \%$ of the dissolved organic carbon species have molecular weights higher than 1000 daltons (1 kDa) (Levine et al., 1985; Grady et al., 1984; Logan and Jiang, 1990). These polymeric compounds in sewage are polysaccharides, polypeptides (proteins), lipoproteins, lipopolysacharides and glycoproteins. Although indigenous bacteria utilise such polymers as a source of energy for growth, these compounds cannot be transported across the cytoplasmic membrane and directly into the cell (Maxham and Maier, 1978). Bacteria must hydrolyse the polymers into monomers by enzymes before metabolising them (Confer and Logan, 1997a and $b$ ). Starch had previously been considered as a model polysaccharide substrate (Banerji et al., 1966 1968) in order to study the mechanism of macromolecular substrate degradation in wastewater

*To whom correspondence should be addressed 
treatment processes. Starch contains two chemically distinct species of glucose polymers: amylose, which is essentially linear, and amylopectin, which is highly branched. In this study, we chose this macromolecular model substrate because its use in industry and everyday life is quite widespread. Starch and its derivatives are present in wastewater from the food and fermentation industries as well as in domestic sewage.

Whereas macromolecular substrate degradation in biological wastewater treatment processes is well documented (Maxham and Maier, 1978; Confer and Logan, 1991; Haldane and Logan, 1994; Confer and Longan, 1997a and b; Ubukata, 1997; Goel et al., 1997, 1998), information on the degradation of these molecules under sewer conditions is scarce (Coulibaly et al., 2002; Coulibaly and Agathos, 2003). Optimising macromolecular substrate hydrolysis in a sewer network could lead to production of assimilable molecules. The consequences of this transformation are rapid metabolism of pollutant and alleviation of the burden on existing underdimensioned treatment plants. A possible strategy to transform macromolecular substrate in sewer lines could be the bioaugmentation of industrial filamentous fungi classified as GRAS (generally regarded as safe) and known for their capacity to depolymerise starch as well as their resistance to toxic pollutants (Coulibaly et al., 2003).

The aims of this research were (i) to study under transitory conditions the degradation of starch by Aspergillus niger, (ii) to determine the effect of fungal inoculum concentration upon starch degradation kinetics, (iii) to measure metabolite accumulation and (iv) to measure the capacity of $A$. niger to secrete enzymes in the growth medium. The fungal strain was chosen for its capacity to excrete hydrolases while at the same time growing in domestic wastewater (Coulibaly and Agathos, 2003; Coulibaly et al., 2006).

\section{MATERIALS AND METHODS}

\section{Microorganisms and Culture Conditions}

A. niger MUCL 28817 was obtained from the fungal collection of the Catholic University of Louvain (MUCL). A. niger was cultivated on tryptic soy agar (TSA) from Difco laboratories (Detroit, Mich., USA) in a 260-ml flat bottle (Nunc, Roskilde, Denmark) at $28^{\circ} \mathrm{C}$ for seven days. Prior to use in the reactor system, $A$. niger was precultured in the medium described by Garcia et al. (1997). Preculture of spores and fungal biomass recovery were carried out as described previously (Coulibaly et al., 2002). Three fungal dry biomass weights $(0.06,1.15$ and $1.8 \mathrm{~g})$ were used to inoculate reactor $\mathrm{R}_{1}$.

\section{Reactor System}

The sewer simulating-system was the reactor system previously described by Coulibaly et al. (2002). Briefly, it is composed of a set of five stirred tanks in series. The system included one membrane pump (Prominent, CfG, Heidelberg, Germany), which fed the first reactor, and four peristaltic pumps (Gilson, Manupilus 2, Namur, Belgium), which linked each reactor to its neighbouring unit. The reactors and the feeding tank were all agitated at 150 rpm with magnetic stirrers (Ika-Combimag RCO, Namur, Belgium). The reactor system was operated at an overall hydraulic residence time (HRT) of $14 \mathrm{~h}$, which is found in long sewer lines (Özer and Kasirga, 1995). The reactor system was inoculated and sampled in the same way as that described in our previous research (Coulibaly et al., 2002). Briefly, each subreactor $\left(R_{1}\right.$ to $\left.R_{5}\right)$ was filled with $500 \mathrm{ml}$ of synthetic wastewater, giving a total volume of $2500 \mathrm{ml}$ for the reactor system. Then the first reactor was inoculated with biomass prepared as indicated above.

All reagents used were of analytical grade.

\section{Synthetic Wastewater Composition}

The synthetic wastewater composition was as follows $(\mathrm{mg} / \mathrm{l}): \quad \mathrm{KH}_{2} \mathrm{PO}_{4}, \quad 700 ; \quad \mathrm{K}_{2} \mathrm{HPO}_{4}, \quad 1400$; $\left(\mathrm{NH}_{4}\right)_{2} \mathrm{SO}_{4}, 195 ; \mathrm{CaCl}_{2}, 50 ; \mathrm{MgSO}_{4} .7 \mathrm{H}_{2} \mathrm{O}, 12.5$; $\mathrm{MnSO}_{4}, 5 ; \mathrm{FeCl}_{3}, 5 ; \mathrm{ZnSO}_{4} .7 \mathrm{H}_{2} \mathrm{O}, 5 ;$ Starch, 500. The $\mathrm{pH}$ of the medium was 6.8 after autoclaving.

\section{Analysis}

The miniaturised starch iodine complex (SIC) method of McCready et al. (1950) was used to monitor the starch concentration in the reactors. The SIC method provides information on polysaccharides having a degree of polymerisation higher than six (Swanson, 1948). Total carbohydrate concentration in the sample was determined by the anthrone method (Dreywood, 1946). Starch hydrolysis product (metabolites with a molecular weight below $1 \mathrm{kDa})$ concentrations were determined by subtraction of the starch content (SIC method) from the carbohydrate content (anthrone method) of each sample. The enzymatic activity profiles of the fungus were determined with the API ZYM kit from 
BioMerieux (Marcy-l'Etoile, France) in accord with the manufacturer's instructions. The API ZYM kit is a standardised semiquantitative micromethod able to detect 19 different types of enzymes and had previously been used to screen enzyme profiles in environmental research (McKellar, 1986; Boczar et al., 1992; Morgan and Pickup, 1993; Cicek et al., 1998). Fungal biomass in the reactors was determined by dry cell weight. Filtration of mixed liquor was done on Whatman No. 4 filter paper, followed by oven drying at $105^{\circ} \mathrm{C}$ (Coulibaly et al., 2002).

\section{RESULTS AND DISCUSSION}

The synthetic wastewater described above was used to study starch degradation in transient regime simulating sewer conditions at $20^{\circ} \mathrm{C}$ and $\mathrm{pH} 6.8$ and with a total hydraulic retention time (HRT) of $14 \mathrm{~h}$ for the reactor system. Experiments were performed under aerobic conditions, and the dissolved oxygen concentration never dropped below $2 \mathrm{mg} \mathrm{O} / 1$. Fungal inoculum concentrations used were $0.12,2.3$ and $3.6 \mathrm{~g} / 1$, and the ratio between them are respectively $1=\frac{0.12}{0.12}, 19.2=\frac{2.3}{0.12}$ and $30=\frac{3.6}{0.12}$. The time course of starch transformation in reactors $R_{1}$ $(\mathrm{HRT}=2.8 \mathrm{~h}), \mathrm{R}_{3}(\mathrm{HRT}=8.4 \mathrm{~h})$ and $\mathrm{R}_{5}(\mathrm{HRT}=14$ h) is shown in Figure 1. These reactors gave information on what happens upstream $\left(\mathrm{R}_{1}\right)$, in the middle $\left(\mathrm{R}_{3}\right)$ and downstream $\left(\mathrm{R}_{5}\right)$ in the reactor system. With the $0.12 \mathrm{~g} / \mathrm{l}$ biomass concentration, a slow starch degradation of $21 \%$ was obtained in $7 \mathrm{~h}$ in reactor $\mathrm{R}_{1}$ (Figure 1 a). Afterwards, starch degradation decreased to attain $11 \%$ in $48 \mathrm{~h}$, but when inoculum concentration was increased from
0.12 to $3.6 \mathrm{~g} / \mathrm{l}$, the degradation kinetics of the starch were modified. About $86 \%$ of the starch was degraded in $7 \mathrm{~h}$ with the $2.3 \mathrm{~g} / \mathrm{l}$ biomass. Thereafter, starch degradation decreased to $0 \%$. With the $3.6 \mathrm{~g} / 1$ biomass concentration, about $98 \%$ of the starch had been degraded at $7 \mathrm{~h}$. Beyond this period the rest of the starch was completely removed from this reactor. However in reactor $\mathrm{R}_{3}$ (Figure $1 \mathrm{~b}$ ), $99 \%$ of the starch had been degraded after $24 \mathrm{~h}$ of incubation with the $3.6 \mathrm{~g} / 1$ biomass concentration but with the $2.3 \mathrm{~g} / 1$ biomass concentration, starch degradation varied between 80 and $96 \%$ in the time interval of 7 to $38 \mathrm{~h}$. After $38 \mathrm{~h}$, a decrease in starch removal was observed. In $R_{3}$, the $0.12 \mathrm{~g} / \mathrm{l}$ fungal biomass concentration gave relatively constant $(17 \%)$ starch degradation after $14 \mathrm{~h}$. In reactor $\mathrm{R}_{5}$, with the 0.12 $\mathrm{g} / \mathrm{l}$ concentration, a maximum starch removal of $34 \%$ was reached in $31 \mathrm{~h}$ of incubation (Figure 1c), but starch degradation was relatively the same for the 2.3 and $3.6 \mathrm{~g} / 1$ inocula. For these two biomass inocula, rapid starch degradation was obtained in $7 \mathrm{~h}$ (65$82 \%$ ). Thereafter, starch removal increased slowly to reach $99 \%$ at $38 \mathrm{~h}$. With the $3.6 \mathrm{~g} / 1$ biomass concentration, starch degradation was maintained at $99 \%$, but a decrease in starch removal was observed with the $2.3 \mathrm{~g} / 1$ concentration. Starch degradation depended on both fungal inoculum concentration and subreactor HRT. This result could be explained by the increase in starch hydrolysis in relation to fungal biomass concentration and the period of contact (important at longer HRTs) between this biomass and starch. As a consequence, more of the starch degrades when the HRT HRT is longer (Coulibaly et al., 2002). The observation of a decrease in starch degradation could be explained by the dilution of the reactor system by the feed and the biomass washout from reactors.

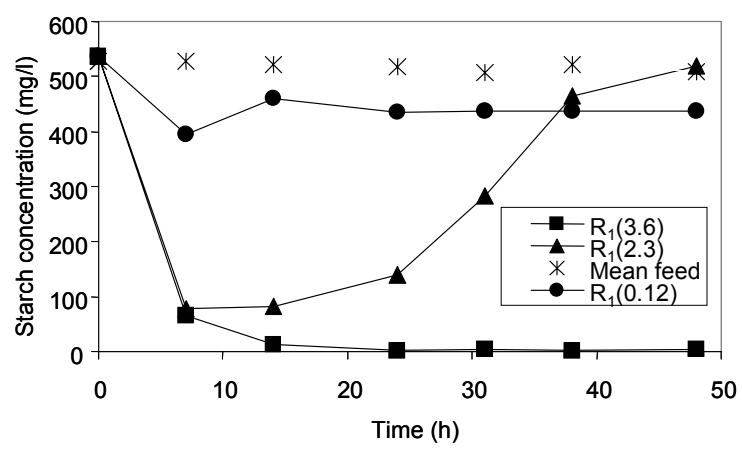

(a)

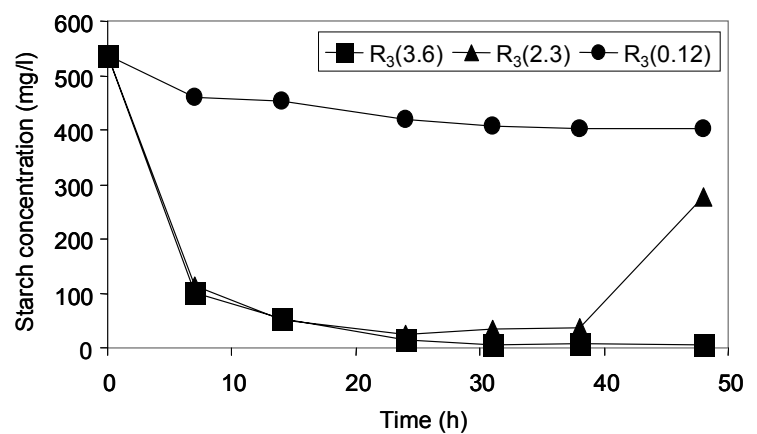

(b) 


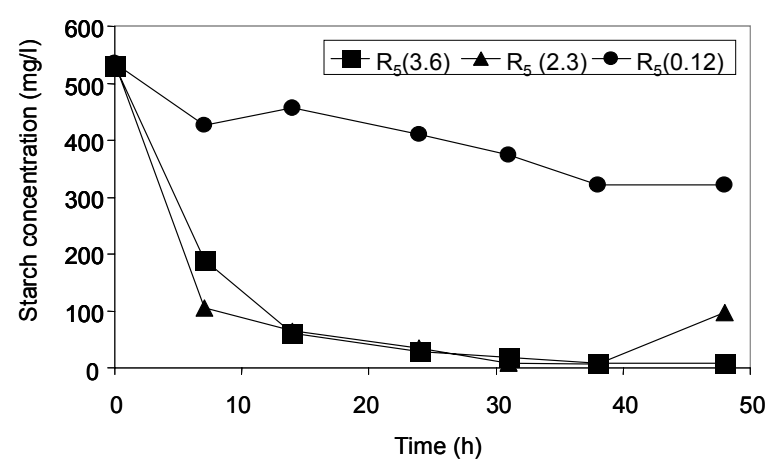

(c)

Figure 1: Kinetics of starch degradation under transitory conditions in the reactor system. (a): $\mathrm{R}_{1}$; (b): $\mathrm{R}_{3}$ and (c): $\mathrm{R}_{5}$

Analysis of starch degradation products (metabolites with a molecular weight below $1 \mathrm{kDa}$ ) allowed showing that they accumulated in the reactor system (Figure 2). In reactor $\mathrm{R}_{1}$ (Figure 2a), metabolites accumulation increased with fungal inoculum concentration. Maximum concentrations of metabolites were observed at $7 \mathrm{~h}$, and those were 144,342 and $387 \mathrm{mg} / \mathrm{l}$ respectively for the $0.12,2.3$ and $3.6 \mathrm{~g} / 1$ biomass concentrations. Beyond $7 \mathrm{~h}$, these concentrations decreased to $0 \mathrm{mg} / \mathrm{l}$ at $40 \mathrm{~h}$ for the 0.12 and $2.3 \mathrm{~g} / 1$ inocula, but with the $3.6 \mathrm{~g} / \mathrm{l}$ concentration, metabolite concentrations were remained relatively constant at $300 \mathrm{mg} / \mathrm{l}$. In reactor $\mathrm{R}_{3}$ (Figure $2 \mathrm{~b}$ ), metabolite profiles were more or less the same for the 2.3 and $3.6 \mathrm{~g} / 1$ inocula. At these

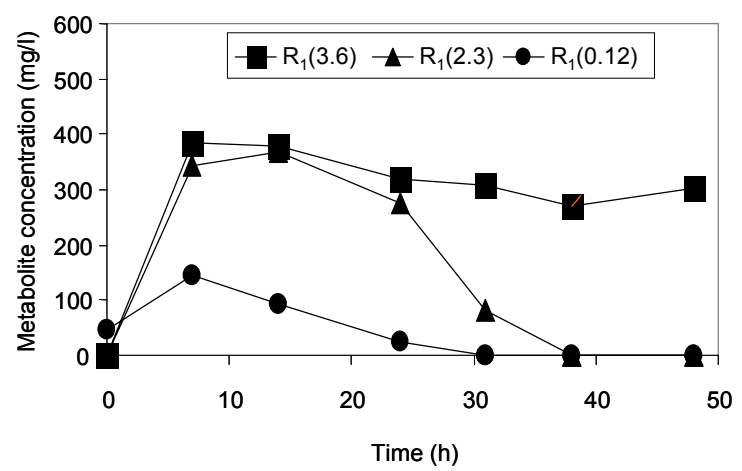

(a) biomass concentrations, maximum metabolite concentrations (322 and $336 \mathrm{mg} / \mathrm{l}$ ) were also observed at $7 \mathrm{~h}$. Thereafter, metabolite accumulation decreased to $70 \mathrm{mg} / \mathrm{l}$ for the $3.6 \mathrm{~g} / \mathrm{l}$ and near $120 \mathrm{mg} / \mathrm{l}$ for the 2.3 $\mathrm{g} / 1$ concentration, but with the $0.12 \mathrm{~g} / \mathrm{l}$ biomass concentration, the maximum metabolite concentrations $(141 \mathrm{mg} / \mathrm{l})$ was obtained in $14 \mathrm{~h}$ and then decreased to $0 \mathrm{mg} / \mathrm{l}$ in $24 \mathrm{~h}$. Metabolite profiles in $\mathrm{R}_{5}$ were relatively the same as those in $\mathrm{R}_{3}$ (Figure 2C), but with the 0.12 $\mathrm{g} / \mathrm{l}$ inoculum, the maximum metabolite concentration was lower $(63 \mathrm{mg} / \mathrm{l})$ than in $\mathrm{R}_{3}$ and became $0 \mathrm{mg} / \mathrm{l}$ at $14 \mathrm{~h}$. The decrease in metabolite accumulation could result from the combined action of their metabolisation, dilution of the reactor system and biomass washout from the reactors.

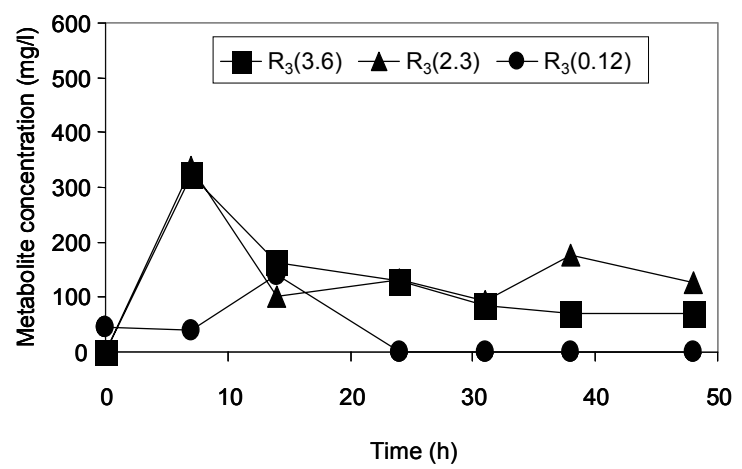

(b)

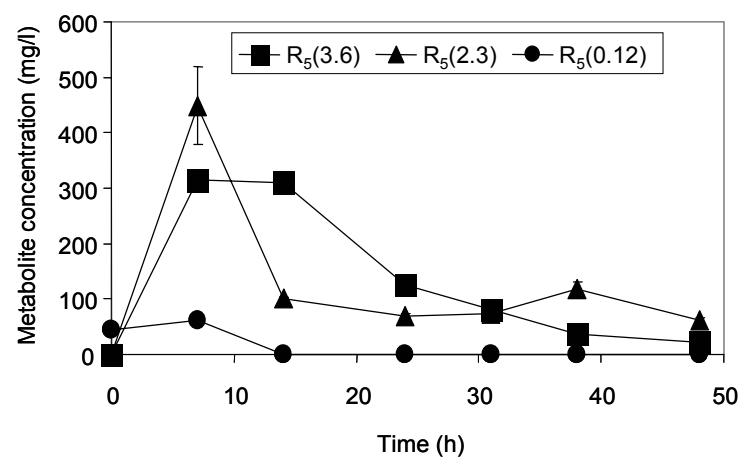

(c)

Figure 2: Accumulation of starch degradation products (metabolites with a molecular weight below $1 \mathrm{kDa}$ ) under transitory conditions in the reactor system. (a): $\mathrm{R}_{1}$; (b): $\mathrm{R}_{3}$ and (c): $\mathrm{R}_{5}$ 
In Figure 3 the time course of biomass in reactors $\mathrm{R}_{1}, \mathrm{R}_{3}$ and $\mathrm{R}_{5}$ is shown for the different inoculum concentrations. For the $0.12 \mathrm{~g} / \mathrm{l}$ concentration, biomass was rapidly washed out of reactor $R_{1}$ and dispersed in $R_{3}$ and $R_{5}$ (Figure 3a). Maximum biomass concentrations in $\mathrm{R}_{3}(43 \mathrm{mg} / \mathrm{l})$ and $\mathrm{R}_{5}(8$ $\mathrm{mg} / \mathrm{l})$ were observed respectively at $7 \mathrm{~h}$ and $14 \mathrm{~h}$. Biomass profiles for the $2.3 \mathrm{~g} / \mathrm{l}$ concentration (Figure $3 \mathrm{~b}$ ) are relatively the same as those for the $0.12 \mathrm{~g} / \mathrm{l}$. After $24 \mathrm{~h}$ of incubation, the biomass had been completely washed out of $R_{1}$. Reactor $R_{3}$ was progressively filled with biomass and reached a maximum biomass concentration $(435 \mathrm{mg} / \mathrm{l})$ at $14 \mathrm{~h}$. The biomass concentration in reactor $\mathrm{R}_{5}$ reached its maximum $(400 \mathrm{mg} / \mathrm{l})$ at $37 \mathrm{~h}$. For the $3.6 \mathrm{~g} / \mathrm{l}$ inoculum, biomass was washed out of reactor $\mathrm{R}_{1}$, but a constant concentration $(600 \mathrm{mg} / \mathrm{l})$ remained beyond $31 \mathrm{~h}$ (Figure 3c). Reactor $\mathrm{R}_{3}$ was progressively enriched with the biomass and its maximum concentration $(800 \mathrm{mg} / \mathrm{l})$ was observed after $24 \mathrm{~h}$. In this reactor, a biomass concentration of about 400 $\mathrm{mg} / \mathrm{l}$ remained. In $R_{5}$, the biomass profile was more or less the same as that in $\mathrm{R}_{3}$. Biomass concentration increased in this reactor to reach a maximum of 437 $\mathrm{mg} / \mathrm{l}$ after $24 \mathrm{~h}$, before decreasing to a constant value of $300 \mathrm{mg} / \mathrm{l}$. Biomass washout of the reactor system for the different inoculum concentrations illustrated the transitory aspect of its functioning. Maintenance of residual biomass in reactors $\mathrm{R}_{1}, \mathrm{R}_{3}$ and $\mathrm{R}_{5}$ when the $3.6 \mathrm{~g} / \mathrm{l}$ fungal biomass concentration was used could be explained by the morphological transformation of the fungal biomass from small pellets to filaments and gross pellets as observed in the reactor system. This fungal morphological transformation is well documented and is attributed to inoculum concentration, $\mathrm{pH}$ and sheer stress (Tung et al., 2004; Pazouki and Panda, 2000). Biomass in filament and gross pellet forms could not be transferred to the adjacent reactor because of its size or adsorption on reactor constituents. This residual biomass could hydrolyse starch; this explains the high accumulation of metabolites in the reactor system inoculated with the $3.6 \mathrm{~g} / \mathrm{l}$ biomass concentration. On the other hand, this biomass could metabolise metabolites when starch had been completely removed; this explains the difference between the metabolite concentrations in $\mathrm{R}_{5}$ for 31 to $48 \mathrm{~h}$ for the 2.3 and $3.6 \mathrm{~g} / 1$ inocula (Figure 2).

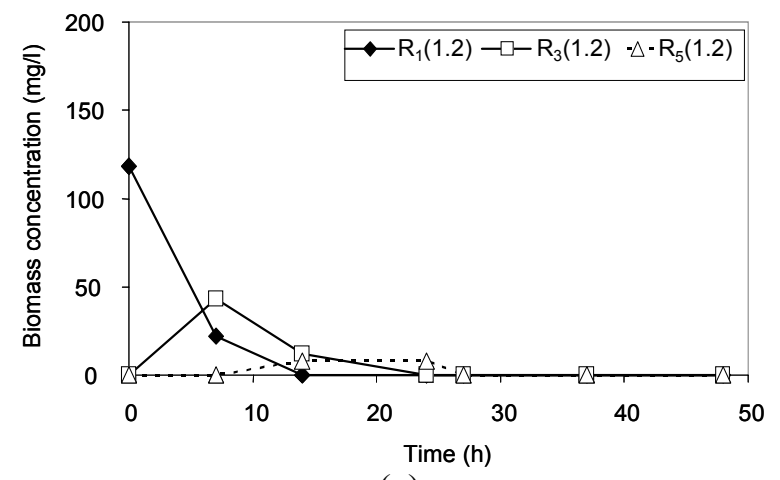

(a)

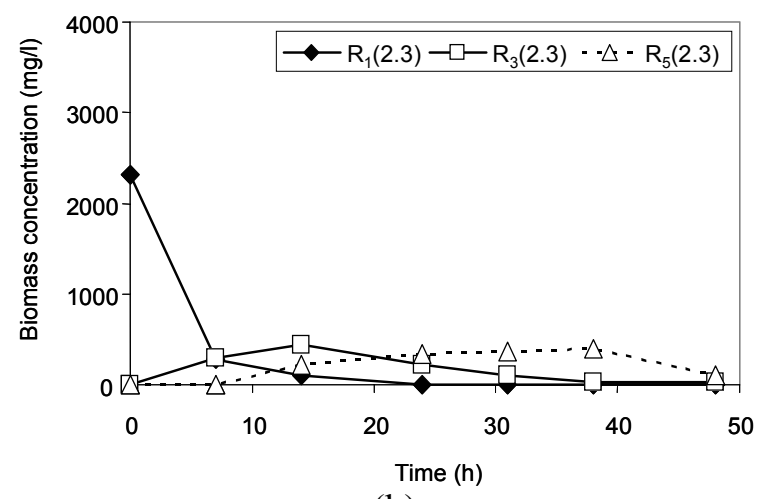

(b)

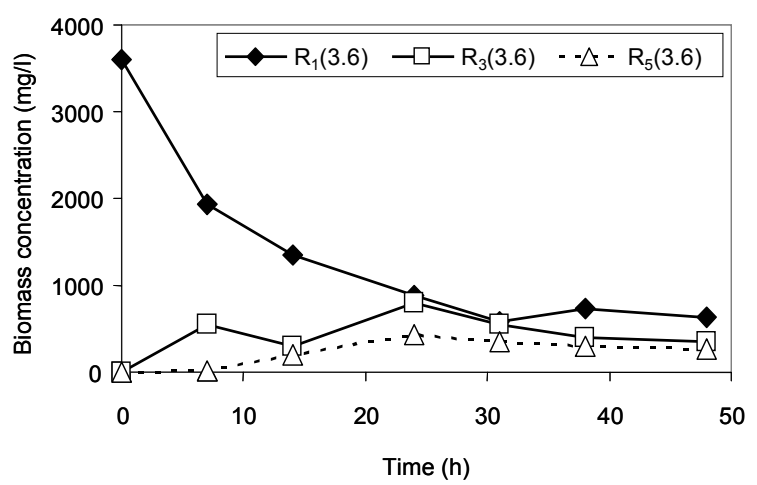

$3(\mathrm{c})$

Figure 3: Biomass profiles in reactors $R_{1}, R_{3}$ and $R_{5}$ for three fungal inoculum concengtrations under transitory conditions in the reactor system. Biomass(a): $0.12 \mathrm{~g} / \mathrm{l} ;(\mathrm{b}): 2.3 \mathrm{~g} / \mathrm{l}$ and (c): $3.6 \mathrm{~g} / \mathrm{l}$ 
An abundant accumulation of metabolites in the reactor system was observed at $7 \mathrm{~h}$ (Figure 2). This result could be explained by the high concentration of biomass in the reactor at $7 \mathrm{~h}$ (Figure 3). This biomass could contribute to starch hydrolysis, as demonstrated below, by the presence of cell-wallbound enzyme on fungal biomass.

To better understand starch degradation by $A$. niger, enzymatic activities of the growth medium (extracellular enzymes) and the cell wall (ectoenzymes) were measured in reactor $\mathrm{R}_{5}$ when the inoculum concentration $3.6 \mathrm{~g} / 1$ was used for starch degradation. Figure $4 \mathrm{a}$ shows the time courses of extracellular enzyme profiles in reactor $R_{5}$. No enzyme activity was characterised at $7 \mathrm{~h}$, probably because of the API ZYM test sensitivity. But after this period, A. niger secreted a pool of enzymes, among which polysaccharidases ( $\alpha$-galactosidase, $\alpha$ glucosidase, glucosaminidase and $\alpha$-manosidase) (Figure 4a). This capacity of A. niger to secrete different enzymes into its growth medium had previously been observed (Coulibaly and Agathos, 2003). It is well known that these enzymes contribute to polysaccharide hydrolysis. Amylase ( $\alpha$ glucosidase and $\alpha$-manosidase) activities were already present at $14 \mathrm{~h}$. The coincidence between amylase activities at $14 \mathrm{~h}$ and reactor system HRT suggest that these enzymes were spontaneously secreted by $A$. niger. For $\alpha$-glucosidase, this activity increased with time to attain a maximum of $50 \mathrm{nmole} / \mathrm{ml} \mathrm{h}$ at $31 \mathrm{~h}$. The maximum activity of the $\alpha$-manosidase ( 37.5 nmole $/ \mathrm{ml} \mathrm{h}$ ) was observed at $38 \mathrm{~h}$. Extracellular enzyme and ecto-enzyme activities in reactor $R_{5}$ at 48 $\mathrm{h}$ are shown in Figure 4b. Enzymatic activities of ecto-enzymes (37.5 - $175 \mathrm{nmole} / \mathrm{ml} \mathrm{h})$ were generally higher than those of extracellular enzymes (12.5 - 50 $\mathrm{nmole} / \mathrm{ml} \mathrm{h}$ ). These results suggest that both fungal biomass and its growth medium could contribute to hydrolysis of starch to provide metabolites. The presence of ecto-enzymes and extracellular enzymes for Aspergillus is well documented (Iwashita et al., 1998; Nagamine et al., 2003). The mechanism of starch degradation by $A$. niger under transient conditions appears to be similar to that proposed for bacterial degradation of macromolecular substrates (Confer and Logan, $1997 \mathrm{a}$ and b).

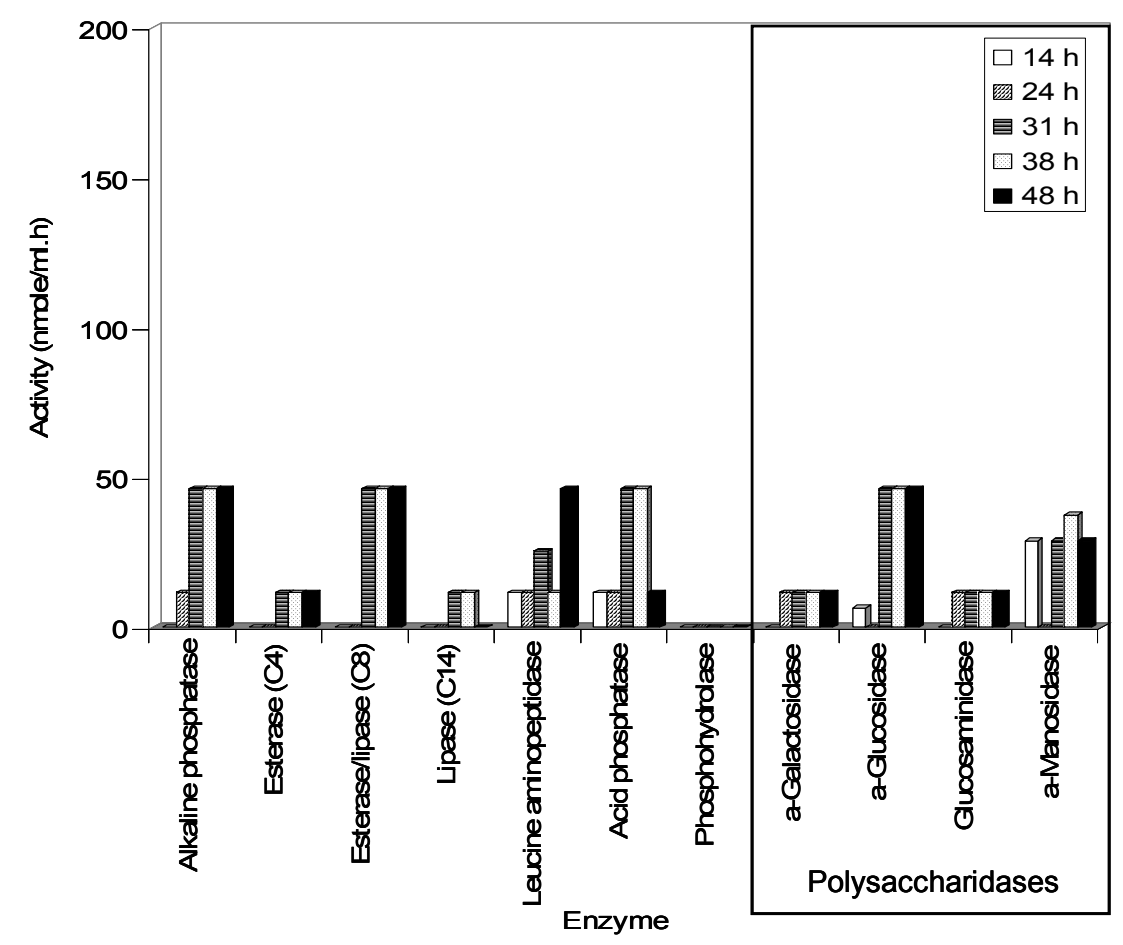

(a) 


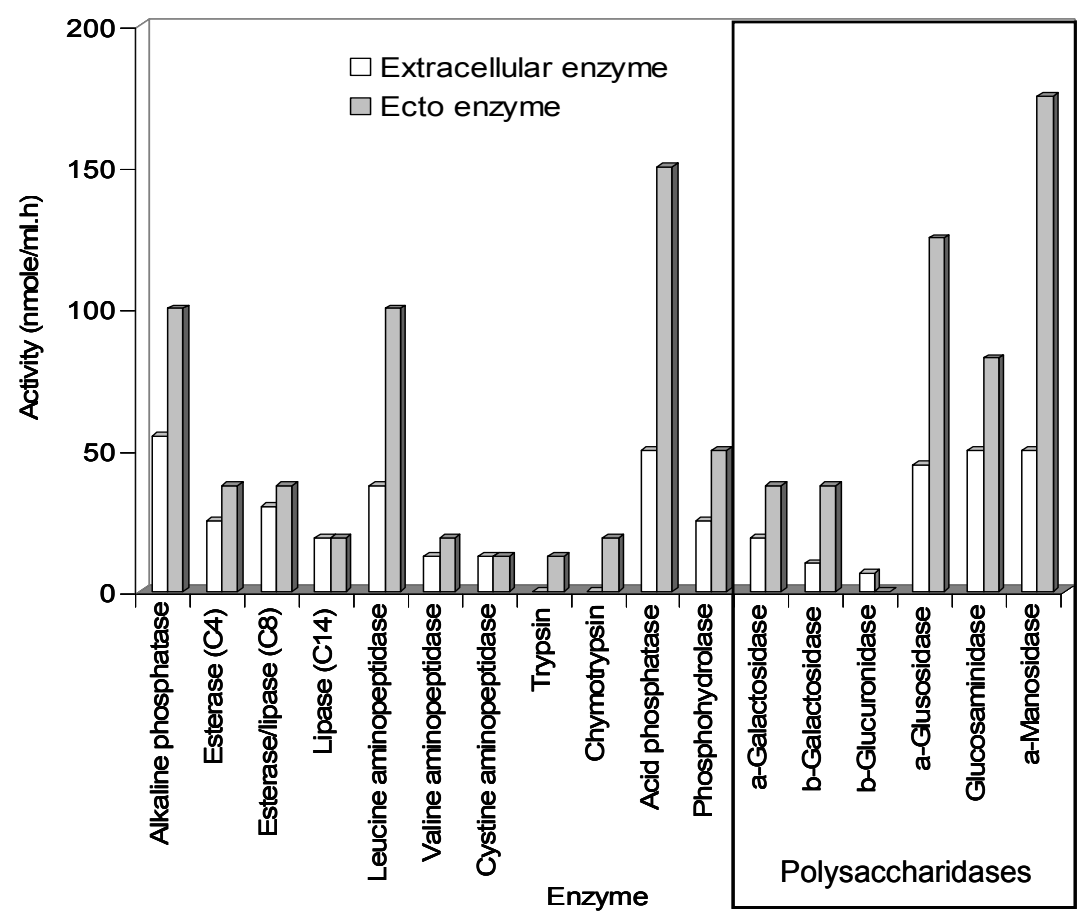

(b)

Figure 4: Enzymatic activities in reactor $R_{5}$ when the reactor system was inoculated with a $3.6 \mathrm{~g} / \mathrm{l}$ concentration of fungal biomass. (a): Time course of extracellular enzymes activities; (b):

Comparison of extracellular enzyme and cell-wall-bound enzyme activities at $48 \mathrm{~h}$

\section{CONCLUSIONS}

A continuous flow reactor was used to simulate transient sewer conditions. At the hydraulic residence time (HRT) of $14 \mathrm{~h}$, starch degradation by A. niger in the system depended on inoculum concentration and subreactor HRT. In the effluent of the final reactor, $99 \%$ of the starch was degraded at fungal biomass concentrations of 2.3 and $3.6 \mathrm{~g} / \mathrm{l}$, but starch degradation was low (34\%) at $0.12 \mathrm{~g} / \mathrm{l}$. An important accumulation of hydrolysis products with a molecular weight lower than $1 \mathrm{kDa}(400 \mathrm{mg} / \mathrm{l})$ had already been observed at $7 \mathrm{~h}$, but metabolite concentrations in the reactor system depended on fungal inoculum concentration. The mechanism of starch degradation by $A$. niger appeared to be the same as that by bacteria. Fungal biomass secreted extracellular and cell wall-bound-enzymes which may contribute to starch hydrolysis. Given the mode of starch degradation by $A$. niger under transient conditions, pretreatment of starch-containing water with this fungi may lead to the release of hydrolytic fragments into solution. This may have considerable implications for treatment systems because the daughter molecules are easily biodegradable. The fungal biomass could be obtained as industrial fermentation waste.

\section{ACKNOWLEDGEMENT}

This research was supported by a fellowship of The Ministry of Higher Education, Scientific Research and Technological Innovation of Côte d'Ivoire. We thank Professor A. M. Corbisier for providing the stock culture of $A$. niger, all the researchers of the Unit of Bioengineering, Laboratoire d'Environnement et de Biologie Aquatique (LEBA) and Dr A. M. Séka for their useful discussions, and H-C. Massart for her analytical support.

\section{REFERENCES}

Banerji, K. S., Ewing, B. B., Engelbrecht, R. S. and Speece, E. R., Mechanism of starch removal in activated sludge process, Proc. $21^{\text {st }}$ Ind. Waste Conf., Purdue Univ., Ext. Sed. 121, pp. 84-102 (1966). 
Banerji, K. S., Ewing, B. B., Engelbrecht, R. S. and Speece E. R., Kinetics of starch removal in activated sludge systems, Journal Water Pollution Control Federation, 40, pp. 161-173 (1968).

Boczar, B. A., Begley, W. M. and Larson, R. J., Characterization of enzyme activity in activated sludge using rapid analyses for specific hydrolases, Water Environment Research, 64, pp. 792-796 (1992).

Cicek, N., Franco, J. P., Suidan, M. T., Urbain, V. and Manem, J., Characterization and comparison of a membrane bioreactor and a conventional activated sludge system in the treatment of wastewater containing high molecular weight compounds, Water Environment Research, 71, pp. 64-70 (1998).

Confer, R. D. and Logan, E. B., Increased bacterial uptake of macromolecular substrates with fluid shear, Applied and Environmental Microbiology, 57, pp. 3093-3100 (1991).

Confer, R. D. and Logan, E. B., Molecular weight distribution of hydrolysis products during the biodegradation of model macromolecules in suspended and biofilm cultures. I. Bovine serum albumin, Water Research, 31, pp. 2127-2136 (1997a).

Confer, R. D. and Logan, E. B., Molecular weight distribution of hydrolysis products during the biodegradation of model macromolecules in suspended and biofilm cultures. II. Dextran and dextrin, Water Research, 31, pp. 2137-2145 (1997b).

Coulibaly, L., Naveau, H. and Agathos, S. N., A tanks-in-series bioreactor to simulate macromolecule-laden wastewater pretreatment under sewer conditions by Aspergillus niger, Water Research, 36, pp. 3941-3948 (2002).

Coulibaly, L. and Agathos, S. N., Transformation kinetics of mixed polymeric substrates under transitory conditions by Aspergillus niger, African Journal Biotechnology, 2, pp. 438-443 (2003).

Coulibaly, L., Gourène, G. and Agathos, N. S., Utilization of fungi for biotreatment of raw wastewaters A Review, African Journal Biotechnology, 2, pp. 620-630 (2003).

Coulibaly, L., Agathos, N. S. and Gourène, G., Enhancement of domestic wastewater treatment under long sewer line condition in a laboratory set-up by Aspergillus niger bioaugmentation, Journal Water Environment \& Technology, 4, pp. 1-7 (2006).
Dreywood, R., Qualitative test for carbohydrate materials, Industrial and Engineering Chemistry Analytical Edition, 18, pp. $499-504$ (1946).

Garcia, G., Bonilla, V. J. L., Jiminez, P. P. R. and Kirchman, L., Biodegradation of phenol compounds in vinasse using Aspergillus terreus and Geotrichum candidum, Water Research, 31, pp. 2005-2011 (1997).

Goel, R., Mino, T., Satoh, H. and Matsuo, T., Effect of electron acceptor conditions on hydrolytic enzyme synthesis in bacterial cultures, Water Research, 31, pp. 2597-2603 (1997).

Goel, R., Mino, T., Satoh, H. and Matsuo, T., Comparison of hydrolytic enzyme systems in pure culture and activated sludge under different electron acceptor conditions, Water Science \& Technology, 37, pp. 335-343 (1998).

Grady, C. P. L. Jr, Kirsh, E. J., Koczwara, M. K., Trogovcich, B. and Watts, R. D., Molecular weight distributions in activated sludge effluents, Water Research, 18, pp. 239-246 (1984).

Haldane, G. M. and Logan, B. E., Molecular size distributions of a macromolecular polysaccharide (dextran) during its biodegradation in batch and continuous cultures, Water Research, 28, pp. 1873-1878 (1994).

Iwashita, K., Todoroki, K., Kimura, H., Shimoi, H. and Ito, K., Purification and characterization of extracellular and cell-bound $\beta$-glucosidase from Aspergillus Kawashii, Bioscience Biotechnology \& Biochemistry, 62, 10, pp. 1938-1946 (1998).

Levine, D. A., Tchobanoglous, G. and Asano, T., Characterization of the size distribution of contaminants in wastewater: Treatment and reuse implication, Journal Water Pollution Control Federation, 57, pp. 805-816 (1985).

Logan, B. E. and Jiang, Q., A model for determining molecular size distributions of DOM, Journal Environment Engineering, 116, pp. 1046-1062 (1990).

Maxham, V. J. and Maier, J. W., Bacterial growth on organic polymers. Biotechnology \& Bioengineering, 20, pp. 865-898 (1978).

McCready, R. M., Guggolz, J., Silviera, V. and Owens, S. H., Determination of starch and amylose in vegetables. Application to peas, Analytical Chemistry, 22, pp. 1156-1158 (1950).

McKellar, R. C., Determination of the extracellular and cell-associated hydrolase profiles of Pseudomonas fluorescens Sp. Using the analytab API ZYM system, Journal Dairy Science, 69, 658-664 (1986). 
Morgan,, J. A. W. and Pickup R. W., Activity of microbial peptidases, oxidases and esterases in lake waters of varying trophic status, Canadian Journal of Microbiology, 39 (8), 795-803 (1993).

Nagamine, K., Murashima, K., Kato, T., Shimoi, H. and Ito, K., Mode of $\alpha$-amylase production by the shochu koji mold Apergillus kawachii, Bioscience Biotechnology \& Biochemistry, 67, pp. 2194-2202 (2003).

Özer, A. and Kasirga, E., Substrate removal in longer sewer lines, Water Science \& Technology, 31; pp. 213-218 (1995).

Pazouki, M. and Panda, T., Understanding the morphology of fungi, Bioprocess Engineering,
22, pp. 127-143 (2000).

Swanson, A. M., Studies on the structure of polysaccharides IV. Relation of the iodine color to the structure, Journal Biological Chemistry, 172, pp. 825-837 (1948).

Tung, T. Q., Miyata, N. and Iwahori, K., Growth of Aspergillus oryzae during treatment of cassava starch processing wastewater with high content of suspended solids, Journal Bioscience \& Bioengineering, 97, pp. 329-335 (2004).

Ubukata, Y., Kinetics of polymeric substrate (dextrin or peptone) removal by activated sludge: Hydrolysis of polymers to monomers is the ratedetermining step, Water Science \& Technology, 36, pp. 159-167 (1997). 